\title{
IS GROWTH RATE MORE IMPORTANT THAN SURVIVAL AND REPRODUCTION IN SHEEP FARMING IN GHANA?
}

\author{
S.Y. Annor, K.T. Djang-Fordjour and K. A. Gyamfi \\ Department of Animal Science Education, University of Education Winneba, \\ P.O. Box 40, Mampong Ashanti, Ghana.
}

\begin{abstract}
The local Djallonké sheep in Ghana is characterized by slow growth and low reproductive rates, but is resistant to most diseases and parasites (survival traits). In an attempt to improve the performance of the local sheep, the Ministry of Food and Agriculture has chosen growth rate as the breeding objective. This is being achieved through the Open Nucleus Breeding Scheme, with the Ejura Sheep Breeding Station being the nucleus farm. The objective of this work was to find out which of the three traits (survival, growth rate and reproduction) is worth including in the breeding objective in the sheep breeding scheme in Ghana. The study was carried out at Ejura Sheep Breeding Station. The method used to compare the three traits involved calculating the economic values of the three traits by using computer models. The economic value of a trait was defined as the marginal profit per ewe per year resulting from a unit increase or decrease in the average value of a trait, whilst holding the average levels of all other traits constant, and at a discount rate of 0 and $12.5 \%$. The results of the study indicated that on average, traits associated with survival had the highest average discounted (12.5\% over the lifetime of the breeding ewe-5.6667 years) economic value (c) 3330.04 or \$0.36). This was followed by reproduction (\$1944.72 or \$0.21) with growth rate recording the lowest average discounted economic value of $\$ 703.96$ or $\$ 0.08$. This means that the order of importance of the three traits with respect to profit maximization in the sheep industry is survival > reproduction > growth rate. It was concluded that all three traits (survival, reproduction and growth rate) should be included in the breeding objective of the sheep breeding scheme in Ghana, instead of concentrating only on growth traits.
\end{abstract}

Keywords: Djallonké sheep, breeding objective, growth rate, survival, reproduction.

\section{INTRODUCTION}

Many small-scale sheep farmers in Ghana face challenges in generating household income. The most important of these challenges are the slow growth and low reproductive rates of local Djallonké sheep. In addition, the exotic Sahelian 
sheep, which is larger in size, and is currently preferred by many farmers, has high mortality rates due to its susceptibility to diseases and parasites.

It has been known for long (Bradford and Berger, 1988; Dickerson, 1969) that the most effective livestock improvement programme can best be attained by effectively using the animals already adapted to a particular environment. Adaptability is the ability to survive and be productive under whatever environment or combination of environments at which the animals are maintained (Terrill and Slee, 1991). Breed comparisons of adaptability and productivity should therefore be done in comparable conditions pertinent to the prevailing production environment.

The identification of adapted breeds, which are relatively superior in important productivity indices, will provide means of enhancing production at no additional input costs. However, there will always be a need to address the whole question of the relationship between the nature of the production environment and the objective of breeding programmes in the context of the level of production and adaptation. For example, Dickerson (1973) has reported that, multiple births and long breeding seasons in meat sheep can be beneficial and could also reduce costs of breeding flocks if appropriate nutrition, housing and labour are provided, but not under stressful range conditions.

It has always been the objective of every breeder to improve the mean performance of traits of economic importance. There is also the need to note which trait is actually of supreme economic importance. This can be achieved by calculating the economic merit for individual traits. Thus, the traits that have to be improved have to be identified and their relative economic importance established.

In an attempt to improve the performance of the local Djallonké sheep, which is resistant to most diseases and parasites (survival traits), the Animal Production Directorate of the Ministry of
Food and Agriculture has chosen a breeding objective of improving the growth rate of the local sheep (LPIU, 2006). This is being achieved through the Open Nucleus Breeding Scheme, with the Ejura Sheep Breeding Station being the nucleus farm (Ahunu et al., 1995). The objective of this work was to find out which of the three traits (survival, growth rate and reproduction) is worth including in the breeding objective in the sheep breeding scheme in Ghana.

\section{METHODOLOGY AND ASSUMPTIONS}

The method used in this work follows the sequential procedure used by Ponzoni (1986), Ponzoni and Newman (1989) and Annor et al. (2000) to calculate the economic values of traits. The method involves the following steps:

- specification of breeding, production and marketing system

- identification of the sources of income and expense

- Specification of biological traits of influencing income and expenses

- Determination of economic values of each trait

The objective of the present methodology was to develop models that were capable of simulating the life cycle production of one breeding ewe and growth performance of her offspring. Simulations were based on life cycle production of one breeding ewe from her birth to culling (over 68 months or 5.6667 years), and generating rams and gimmers for sale at different parities.

\section{Ejura Sheep Breeding, Production and Mar- keting System}

The study was carried out at Ejura Nucleus Sheep Breeding Station. The Ejura Nucleus Breeding Station uses the West African Dwarf (Djallonké) sheep for production. The production programme actually focuses on the improvement of growth rate of Djallonké sheep and to supply improved males to multipliers or participating breeders who will multiply and sell same to farmers for further production. 
Sheep housing at the station is made of permanent concrete structures from the ground level to a height of one meter, and it is continued with wire mesh up to the ceiling to aid ventilation. It is roofed with corrugated iron sheet and is partitioned into various pens based on sex, age, and breeding purposes. Available in each pen are feeding and drinking troughs, and crush pens. The floors are cemented and sloped gently to ensure easy flow of urine, and also to promote easy drainage and scrubbing.

The sheep graze on pasture as well as the rangeland. Pasture consists of Centrosema pubescens, Cynodon plectostachyus (Giant star grass), Panicum maximum (Guinea grass), Ficus indica, Cajanus cajan and Stylosanthes hamata. Supplementary feeds including rice straw, hay, concentrates, brewers' spent grain, palm kernel cake and cassava peels are also fed to the animals.
Feed supplements are mostly fed to the animals during the dry season, and to nursing mothers.

Deworming as well as deticking are some health practices carried out on the farm to control endoand ecto-parasites respectively. All sick animals are mostly identified and isolated for treatment. Antibiotics are used for the treatment of diseases such as pneumonia, enteritis, dysentery and mastitis. Animals are also vaccinated against Pest de Petite Ruminant (PPR) each year. Deworming and deticking are done twice in every month during the raining season, whereas in the dry season, deworming is done once every month.

The farm is managed by one farm manager and three technical officers. Other workers are six stockmen whose activity is to shepherd the flock during grazing. Other supporting staff includes a typist, an account officer, four security officers and two fencers. Fencers repair all spoilt fences

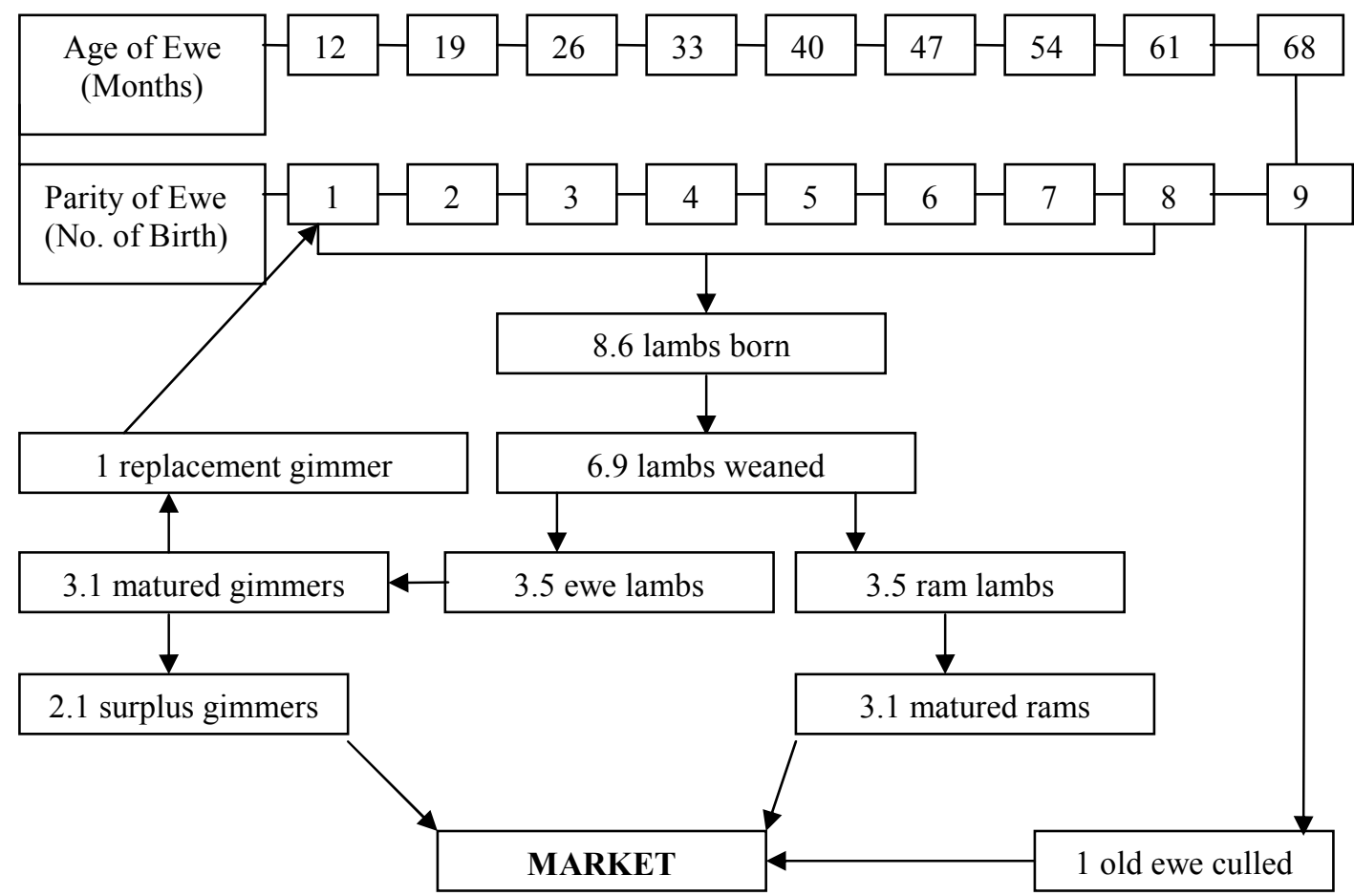

Fig. 1: Model flow diagram for one ewe and her offspring derived from average values of all traits 
and set new fences in case the need arises. Apart from mending fence, the fencers weed around the farm and they also provide regular cleaning and disinfection of pens.
Fig. 1 shows the life cycle of one breeding ewe from birth to first lambing at 12 months to last parity at 68 months when it is culled out to the market, and replaced by one gimmer.

Table 1: Values of input and output parameters

\begin{tabular}{|c|c|}
\hline Parameter & Value \\
\hline Number of breeding ewe & 1.00 \\
\hline Number of breeding ram & 1.00 \\
\hline Age at first parturition (months) & 12.00 \\
\hline Ewe fertility rate $(\%)$ & 80.00 \\
\hline Litter size at birth & 1.06 \\
\hline Length of life cycle of ewe (months) & 68.00 \\
\hline Parturition interval (months) & 7.00 \\
\hline Sex Ratio (\% males:females) & $50: 50$ \\
\hline Survival rate from birth to weaning $(\%)$ & 88.00 \\
\hline Survival rate from weaning to maturity (\%) & 91.00 \\
\hline Birth weight of ram lambs $(\mathrm{kg})$ & 1.92 \\
\hline Birth weight of ewe lambs (kg) & 1.83 \\
\hline Weaning weight of ram lambs $(\mathrm{kg})$ & 8.81 \\
\hline Weaning weight of ewe lambs $(\mathrm{kg})$ & 8.56 \\
\hline Mature weight of young rams $(\mathrm{kg})$ & 18.00 \\
\hline Mature weight of gimmers (kg) & 17.00 \\
\hline $\begin{array}{l}\text { Weight of breeding ewe }(\mathrm{kg}) \\
\text { Weight of breeding ram }(\mathrm{kg})\end{array}$ & $\begin{array}{l}25.00 \\
35.00\end{array}$ \\
\hline $\begin{array}{l}\text { Days from birth to weaning } \\
\text { Days from weaning to maturity }\end{array}$ & $\begin{array}{l}120.00 \\
245.00\end{array}$ \\
\hline Days from birth to start of feed intake & 14.00 \\
\hline Average price per $\mathrm{kg}$ of marketed sheep (cedis $/ \mathrm{kg}$ ) & $20,000.00$ \\
\hline Preweaning cost of veterinary services charges and drugs/animal (cedis) & $2,353.72$ \\
\hline Postweaning cost of veterinary services charges and drugs/animal (cedis) & $4,707.45$ \\
\hline Cost $/ \mathrm{kg}$ dry matter of pasture (cedis $/ \mathrm{kg}$ ) & 200.00 \\
\hline Discount rate $(\%)$ & 0 or 12.5 \\
\hline Number of parturitions/ewe/lifetime & 9.00 \\
\hline Preweaning daily intake of pasture dry matter by ram lamb $\left(\mathrm{kg} / \mathrm{kgW}^{\wedge} 0.75\right)$ & 0.08 \\
\hline Preweaning daily intake of pasture dry matter by ewe lamb $\left(\mathrm{kg} / \mathrm{kgW}^{\wedge} 0.75\right)$ & 0.075 \\
\hline Postweaning daily intake of pasture dry matter by young ram $\left(\mathrm{kg} / \mathrm{kgW}^{\wedge} 0.75\right)$ & 0.095 \\
\hline Postweaning daily intake of pasture dry matter by gimmer $\left(\mathrm{kg} / \mathrm{kgW}^{\wedge} 0.75\right)$ & 0.090 \\
\hline Daily pasture dry matter intake by breeding ewe $\left(\mathrm{kg} / \mathrm{kgW}^{\wedge} 0.75\right)$ & 0.11 \\
\hline Daily dry matter intake by breeding ram $\left(\mathrm{kg} / \mathrm{kgW}^{\wedge} 0.75\right)$ & 0.11 \\
\hline Preweaning daily gain of ram lamb (kg/day) & 0.057 \\
\hline Preweaning daily gain of ewe lamb (kg/day) & 0.056 \\
\hline Postweaning daily gain of young ram (kg/day) & 0.038 \\
\hline Postweaning daily gain of gimmer ( $\mathrm{kg} / \mathrm{day})$ & 0.034 \\
\hline
\end{tabular}

26 Journal of Science and Technology, Vol. 27, No. 3, December 2007 
The biological parameters that were used to construct Fig. 1 are shown in Table 1. It was assumed that the ewe completes its entire life cycle over 68 months or 5.6667 years, and is replaced by one gimmer at the end of its life cycle. All other females apart from one replacement gimmer were sold. All males were also sold (Fig. 1).

\section{Determination of the Sources of Income and Expenses}

The sale of animals and government subvention was the main source of income for the farm. Breeding males were sold to multipliers for breeding and multiplication purposes. Unproductive as well as old animals were also sold out for meat to obtain income. The average selling price of a sheep was $₫ 20,000$ per kilogram live weight (Table 1).

Expenses involved both variable and fixed costs. Fixed cost included housing, pasture and pasture fencing, veterinary equipment, water, breeding animals, labour cost and electricity. Variable cost also included veterinary services charges and drugs (deworming, deticking, antibiotics, vaccination and wound treatment), and feed (Table 1).

\section{Identification of Traits Influencing Income and expenses}

Economic values were calculated for the following traits:

Reproductive traits:

- $\quad$ Ewe fertility rate (EFR)

- $\quad$ Litter size at birth (LSB)

- $\quad$ Lambing interval (LI)

- End of Life Cycle of Breeding Ewe (ENDLIFE)

- $\quad$ Age at first lambing (LAMBFIRST)

Survival traits:

- $\quad$ Survival from birth to weaning (SWB)

- $\quad$ Survival from weaning to maturity (SWM)
Growth traits:

- $\quad$ Ram lamb daily weight gain (rLPRDG)

- $\quad$ Ewe lamb daily weight gain (eLPRDG)

- Ram post -weaning daily weight gain (rPODG)

- Ewe post-weaning daily weight gain (gPODG)

\section{Derivation of Economic Values of Traits}

The method of deriving economic values was to utilize profit equations. It involved combining income and expense as a function of profit, where profit was derived from the difference between income and expense. The economic value of a trait was defined as the marginal profit per ewe per year resulting from one unit increase or decrease in the value of each trait, under the condition that performance levels of all other traits are held constant, at their mean values. This procedure, known as the partial budgeting approach (Upton et al., 1988; Barwick, 1992), is demonstrated in equations 1, 2, 3, 4 and 5 below:

PI = MR1-MC1------------------------------------ 1

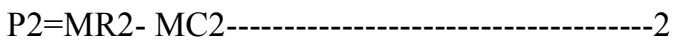

Therefore MP= P2-P1------------------------------3

Putting 1) and 2) into 3)

$\mathrm{MP}=(\mathrm{MR} 2-\mathrm{MC} 2)-(\mathrm{MR} 1-\mathrm{MC} 1)$------------4

Where $\mathrm{MP}=$ Marginal Profit

$$
E V=\frac{M P}{E L}
$$

$\mathrm{P} 1=$ profit per ewe before genetic improvement $\mathrm{P} 2=$ profit per ewe after genetic improvement $\mathrm{MC1}=$ marginal cost per ewe before genetic improvement

$\mathrm{MC} 2=$ marginal cost per ewe after genetic improvement

MR1 = marginal returns per ewe before genetic improvement

MR2= marginal returns per ewe after genetic improvement

$\mathrm{EL}=$ end of life cycle of ewe in years $(5.6667$ years)

$\mathrm{EV}=$ economic value (marginal profit per ewe per year) 
The analysis was done in a partial budgeting framework by considering only those parts or items of the budget that change. Fixed costs were ignored, since income and expense were combined as a difference, and do not include the items of the budget that do not change (Ponzoni, 1986). Appendix 1 shows the cost-benefits streams of traits over the life time of a ewe.

The combined life cycle profit was scaled down from a life time profit to a per ewe-year basis by dividing marginal profit by the total number of years in which a ewe completes its entire life cycle (Equation 5). Calculating profit in oneyear yields allows for frequency of expression of traits (Ponzoni and Newman, 1989). All costs and returns were discounted over the lifetime of the breeding ewe (68 months or 5.6667 years), taking into account the time of expression of traits (Smith, 1978) by applying the expression below at a discount rate of 0 and $12.5 \%$.

$$
\frac{1}{(1+D F)} t
$$

Where $D F$ is the discount rate and $t$ is the number of years of expression of a trait. The $12.5 \%$ discount rate represented the inflation rate in Ghana as at the time of preparing the manuscript. In doing economic analysis of a livestock enterprise the inflation rate at that time could be used as the discount rate (Smith, 1978). The two discount rates (0 and $12.5 \%$ ) were chosen in order to make allowance for adjusting net profit (at $0 \%$ discount rate) to allow for a decrease in value of the future net returns by using the $12.5 \%$ discount rate, which was the inflation rate at the time of carrying out the research. This implies that at $0 \%$ discount rate benefits/costs to be received/incurred in future have the same value today as in future; that is the future benefits/costs are not discounted at all.

\section{RESULTS}

\section{Reproductive Traits}

The values obtained as a result of $1 \%$ increase or decrease in the average values of reproductive traits at $0 \%$ and $12.5 \%$ discount rates are presented in the Table 2. The average economic value obtained for the reproductive traits at $0 \%$ and $12.5 \%$ discount rates were $\phi 2286.07$ and $\phi$ 1944.72, respectively. EFR and LSB were the traits with the highest economic values. EFR and LSB also had the same economic values. Economic Values for ENDLIFE regressed greatly towards zero more than any other trait when discounted. It can also be observed that LAMBFIRST was the trait with the lowest economic value.

\section{Survival traits}

The average value obtained for the survival traits were $\notin 3746.3$ and $ф 3330.04$ at $0 \%$ and $12.5 \%$ discount rates respectively (Table 3 ). The value for SWM was slightly higher than that of SBW.

Table 2: Economic values for reproductive traits.

\begin{tabular}{lcc}
\hline \multicolumn{1}{c}{ Traits } & $\mathbf{0 \%}$ Discount Rate $(\boldsymbol{c})$ & $\mathbf{1 2 . 5} \%$ Discount Rate (c) \\
\hline EFR & 3343.67 & 2972.15 \\
LSB & 3343.67 & 2972.15 \\
LI & 3002.17 & 2668.60 \\
ENDLIFE & 1103.98 & 544.56 \\
LAMBFIRST & 636.89 & 566.12 \\
Average & $\mathbf{2 2 8 6 . 0 7}$ & $\mathbf{1 9 4 4 . 7 2}$ \\
\hline
\end{tabular}

28 Journal of Science and Technology, Vol. 27, No. 3, December 2007 


\section{Growth Traits}

The average economic values for growth traits were $\varnothing 791.96$ and $\varnothing 703.96$ at $0 \%$ and $12.5 \%$ discount rates respectively (Table 4). Among the growth traits rPODG had the highest economic value, followed by both rLPRDG and eLPRDG with gPODG having the lowest economic value.

\section{General Observations}

The results of the study indicated that on average, traits associated with survival had the highest discounted economic value (\$3330.04). This was followed by reproduction ( $\not 1944.72)$ with growth rate recording the least economic value of $\notin 703.96$.

\section{DISCUSSION}

\section{Reproductive Traits}

It could be observed that among the reproductive traits EFR and LSB had the same economic values (Table 2). This pre-supposes that the correlation between the two traits is +1 . An increase in one of them may lead to a proportionate increase in the other. Again, EFR and LSB had the highest economic values when compared to other reproductive traits, indicating that they are the two most important traits in terms of reproduction. Among the reproductive traits, LAMB-
FIRST was the trait with the lowest economic value (Table 2). This gives an indication that the age at first lambing of Djallonké breed is long. In other words the breed matures and gives birth late.

ENDLIFE regressed to zero more than any other reproductive trait (Table 2), because of the longer time of expression of the trait at the end of the life cycle. When an animal stays longer in the flock, it becomes less productive and expensive to maintain in terms of feed and husbandry. Again, at that old age, the animal's market price may reduce.

\section{Survival Traits}

SWM had a slightly higher economic value than SBW (Table 3), although mortality rate from birth to weaning was greater than that from weaning to maturity (Table 1). This is because lambs are more susceptible and more vulnerable to diseases and parasitic infections than when they are older. In that case, the cost of production incurred in the husbandry of the young lambs before weaning would be higher than that from weaning to maturity. The returns associated with the preweaning stage is also lower than that of the post weaning stage. These factors interact to give lower economic values for SBW compared to SWM.

Table 3: Economic values for survival traits

\begin{tabular}{lcc}
\hline Traits & 0\% Discount Rate (d) & $\mathbf{1 2 . 5} \%$ Discount Rate (d) \\
\hline SBW & 3690.59 & 3280.52 \\
SWM & 3802.01 & 3379.56 \\
Average & $\mathbf{3 7 4 6 . 3}$ & $\mathbf{3 3 3 0 . 0 4}$ \\
\hline
\end{tabular}

Table 4: Economic values for growth traits

\begin{tabular}{lcc}
\hline Traits & $\mathbf{0 \%}$ Discount Rate (⿻) & $\mathbf{1 2 . 5} \%$ Discount Rate (⿻) \\
\hline rLPRDG & 782.13 & 695.22 \\
eLPRDG & 782.13 & 695.22 \\
rPODG & 1064.56 & 946.28 \\
gPODG & 539.01 & 479.12 \\
Average & $\mathbf{7 9 1 . 9 6}$ & $\mathbf{7 0 3 . 9 6}$ \\
\hline
\end{tabular}




\section{Growth Traits}

Among the growth traits rPODG had the highest economic value compared to rLPRDG and eLPRDG because of the length of time involved in each of these stages of life. Growth early in life (rLPRDG and eLPRDG) is short compared to late growth (rPODG) in life. Rapid growth early in life does not increase the amount of product produced, as slow growth later in life would do, because end points are completely determined by passage of time (Mac Neil et al., 1994). gPODG had the lowest economic values than all other growth traits because one gimmer was used to replace the old ewe. This reduced the returns associated with gPODG, and thus reducing its economic value. This means that small dams that have higher litter size and wean their litters successfully are required in meat sheep production (Dickerson, 1973).

The results of this study indicated that on average, the order of importance of the traits with respect to profit maximization in the sheep industry in Ghana, is Survival> Reproduction $>$ Growth rate.

A similar work conducted by Upton (1985) in Nigeria and Greeff et al. (1995) in South Africa suggested that the most critical area, where improvements were most needed, was that of reducing mortality and increasing survival. Annor et al. (2000) also observed in beef cattle in Ghana that survival traits had the highest economic value, followed by reproduction with growth rate having the lowest economic value. Baker and Rege (1994) also pointed out that in most subsistence tropical farming systems, survival in the face of multiple stresses (heat, diseases, etc.) is one of the most important economic traits, while increasing growth rate is of less economic value.

However, Mac Neil et al. (1994) reported conflicting results to the current study. They observed that economic values for male fertility, female fertility and calf survival were smaller compared to the economic value of growth rate. In their studies, post-weaning growth rate was the trait with the highest economic value. In another study (Rewe et al., 2006), reproductive traits had the highest economic values followed by survival and feed intake in that order.

\section{CONCLUSION AND RECOMMENDATION}

The present study shows that survival and reproductive traits are the most important traits contributing towards improved profitability in the Djallonké sheep industry in Ghana. Growth rate per se, which has been selected as the objective of genetic improvement in sheep production in Ghana by the Ministry of Food and Agriculture is not important compared to survival and reproduction.

By the application of the selection index theory which optimizes the efficiency of animal production by combining different traits in a breeding programme (Van Vleck et al., 1987), it is recommend that all the three traits (survival, reproduction and growth rates) need to be included in the breeding objective of the sheep breeding scheme in Ghana by the Ministry of Food and Agriculture, instead of concentrating only on growth traits.

\section{REFERENCES}

Ahunu, B.K., Boa-Amponsem, K., Okantah, S.A., Aboagye, G.S. and Buadu, M.K. (1995). National Animal Breeding Plans for the Republic of Ghana. A Report on National Livestock Genetic Improvement submitted to the Ministry of Food and Agriculture, Accra, Ghana, 172pp.

Annor, S.Y., Garrick, D.J. and Blair, H.T. (2000). Economic values of traits for beef production in Ghana. Bulletin of Animal Health and Production in Africa, 48: 97-110.

Baker, R.L. and Rege, J.E.O. (1994). Genetic resistance to disease and other stresses in improvement of ruminant livestock in the tropics. Proceedings of the Fifth World Congress on Genetics Applied to Livestock Production 20:405-410. 
Barwick, S. 1992. Introducing economics to modern animal breeding. In: Animal Breeding, The Modern Approach. A postgraduate foundation publication. Ed. K. Hammond, H-U. Graser and C.A. McDonald, pp.121139.

Bradford, G. E. and Berger, Y. M. (1988). "Breeding strategies for small ruminants in arid and semi-arid areas. "In: Thomson, E. F. and Thomson, F. S. (eds.). Increasing Small Ruminant Productivity in Semi-Arid Areas. Proc. Conf. held at ICARDA, Aleppo, Syria, Current Topics in Vet. Med. and Anim. Sci. 47: 95 -109.

Dickerson, G.E. (1973). Inbreeding and heterosis in animals. In: Proceedings of an Animal Breeding Symposium in honour of Jay Lush. American Society of Animal Science and American Dairy Science Association, Champaign, Illinois, USA. pp. 54-77

Dickerson, G. E. (1969). "Experimental approaches in utilising breed resources." Animal Breeding Abstract. 37 (2): 191-202.

Greeff, J.C., Bouwer, L. and Hofmeyr, J.H. (1995). Biological efficiency of meat and wool production of seven sheep genotypes. Animal Science, 61: 259-264.

Livestock Production and Information Unit (LPIU) (2006). Ghana National Livestock Breeding Policy. Animal Production Directorate, Ministry of Food and Agriculture, $10 \mathrm{pp}$.

MacNeil, M.D., Newman, S., Enns, R.M. and Stewart-Smith, J. (1994). Relative economic values for Canadian beef production using specialized sire and dam lines. Canadian Journal of Animal Science, 74: 411417.

Ponzoni, R.W. (1986). A profit equation for the definition of breeding objective of Australian Merino Sheep. Journal of Animal Breeding and Genetics, 103: 342-357.
Ponzoni, R.W. and Newman, S. (1989). Developing breeding objectives for Australian cattle production. Animal Production, 49: 3547.

Rewe, T.O., Indetie, D., Ojango, J.M.K and Kahi, A.K. (2006). Economic values for production and functional traits and assessment of their influence on genetic improvement in the Boran cattle in Kenya. Journal of Animal Breeding and Genetics, 123 (1): 23-36.

Smith, C. (1978). The effect of inflation and form of investment on the estimated value of genetic improvement in farm livestock. Animal Production, 26: 101-110.

Terrill, C. E. and Slee, J. (1991). "Breed differences in adaptation of sheep. "In: Maijala, K. (ed.). Genetic Resources of pig, sheep and goat. World Animal Science, B8. Elsevier Science Publishers B. V. pp. 195-233.

Upton, M. (1985). Returns from small ruminant production in South West Nigeria. Agricultural Systems, 17: 65-83.

Upton, W.H., McArthur, A.T.G. and Farquharson, R.J. (1988). Economic values applied to breeding objectives: a decentralized approach for breedplan. Proceedings of the Seventh Conference of Australian Association of Animal Breeding and Genetics, pp. 95-104.

Van Vleck, L.D., Pollak, J.E. and Oltenacu, E.A.B. (1987). In: Genetics for the Animal Sciences. W.H. Freeman and Company, New York, 391pp. 
APPENDIX 1: Cost-benefits (Cedis) streams of traits over the life time of ewe

\begin{tabular}{|c|c|c|c|c|c|c|c|}
\hline \multirow{2}{*}{ Trait } & \multicolumn{2}{|c|}{ Undiscounted Cost of Production } & \multicolumn{2}{|c|}{ Undiscounted Returns } & \multicolumn{2}{|c|}{ Marginal Returns } & \multirow{2}{*}{$\begin{array}{l}\text { Marginal } \\
\text { Profit } \\
\text { MP }\end{array}$} \\
\hline & $\mathrm{MC} 1$ & $\mathrm{MC} 2$ & MR1 & MR2 & P1 & P2 & \\
\hline EFR & 1679257.86 & 1681855.12 & 2264472.07 & 2286016.79 & 585214.21 & 604161.66 & 18947.46 \\
\hline LSB & 1679257.86 & 1681855.12 & 2264472.07 & 2286016.79 & 585214.21 & 604161.66 & 18947.46 \\
\hline LI & 1679257.86 & 1681589.86 & 2264472.07 & 2283816.37 & 585214.21 & 602226.51 & 17012.30 \\
\hline ENDLIFE & 1679257.86 & 1696256.57 & 2264472.07 & 2287726.69 & 585214.21 & 591470.12 & 6255.91 \\
\hline LAMBFIRST & 1679257.86 & 1679752.57 & 2264472.07 & 2268575.82 & 585214.21 & 588823.25 & 3609.04 \\
\hline SBW & 1679257.86 & 1679889.24 & 2264472.07 & 2286016.79 & 585214.21 & 606127.55 & 20913.34 \\
\hline SWM & 1679257.86 & 1695614.26 & 2264472.07 & 2302373.19 & 585214.21 & 606758.93 & 21544.72 \\
\hline rlPRDG & 1679257.86 & 1696050.44 & 2264472.07 & 2285696.70 & 585214.21 & 589646.26 & 4432.05 \\
\hline elPRDG & 1679257.86 & 1696050.44 & 2264472.07 & 2285696.70 & 585214.21 & 589646.26 & 4432.05 \\
\hline rPODG & 1679257.86 & 1684855.39 & 2264472.07 & 2276102.12 & 585214.21 & 591246.73 & 6032.52 \\
\hline gPODG & 1679257.86 & 1681800.21 & 2264472.07 & 2270068.81 & 585214.21 & 588268.60 & 3054.39 \\
\hline
\end{tabular}




\title{
SEARCH FOR SCUTELLONEMA BRADYS RESISTANCE IN YAMS (DIOSCOREA SPP.)
}

\author{
C. K. Kwoseh ${ }^{1}$, R. A. Plowright ${ }^{2}$, J. Bridge ${ }^{2}$ and R. Asiedu ${ }^{3}$ \\ ${ }^{1}$ Department of Crop and Soil Sciences, \\ Kwame Nkrumah University of Science and Technology, Kumasi, Ghana \\ ${ }^{2}$ CABI Bioscience UK Centre, Bakeham Lane, Egham, Surrey TW20 9TY, UK \\ ${ }^{3}$ International Institute of Tropical Agriculture (Nigeria), c/o LW Lambourn and Co., Carolyn House, \\ 26 Dingwall Road, Croydon CR9 3EE, UK
}

\begin{abstract}
A study to examine variability in susceptibility of yams to Scutellonema bradys and to identify possible sources of resistance in Ghanaian yam germplasm (Dioscorea spp.) for use in yam improvement programmes, particularly, in West Africa was undertaken. Pot and field screening methodologies were used. In general, S. bradys and dry rot of tuber symptoms as well as tuber cracking increased during the storage period. The study showed a positive correlation between visual nematode damage and population densities in yam tubers. There was also a linear relationship between dry rot disease and tuber cracking at harvest and during storage. This confirms that $S$. bradys causes dry rot of tubers resulting in external cracking of yam tubers. Positive linear relationship was also observed between yam tuber weight loss and dry rot disease indicating that dry rot disease may have contributed to the tuber weight loss. Therefore, tuber dry rot symptoms caused by S. bradys of yams could be used to discard susceptible yams at harvest and after a period of storage. However, there was no linear relationship between nematode population densities in yam tubers and roots, therefore, a root protocol cannot be used for assessing resistance in yams as it could lead to misclassification. The yam germplasm screened, reaffirmed resistance to S. bradys in Dioscorea dumetorum var. Nkanfo and D. cayenensis var. Afun.
\end{abstract}

Keywords: Scutellonema bradys, Nematode, Dioscorea, Yam, Resistance

\section{INTRODUCTION}

The yam nematode, Scutellonema bradys is a major nematode pest of yams, particularly, in West Africa causing severe damage to yam tubers (Adesiyan et al., 1990; Jatala and Bridge, 1990; Emehute et al., 1998). It is the most important and prevalent nematode on yam in
Ghana (Plowright and Kwoseh, 1998), largely determining yam tuber quality and storability. They can cause a reduction of $20-30 \%$ in tuber weight at harvest (Smit, 1967). According to Coursey (1967), nematode infection contributes to long term storage losses and has been estimated as $50 \%$. In severe cases, loss may be total. 
S. bradys also acts as wounding agents and creates infection courts in tuber for fungi and bacteria to gain entry easily and cause wet rot (Bridge, 1982).

Yams, when grown as a subsistence crop, are generally not treated with pesticides and chemical treatments are not widely used for nematode control. Farmers have therefore relied on natural variation for their selection of suitable varieties of yam to cope with the damage caused by plant parasitic nematodes. Nematode resistant yam cultivars can be one of the most useful, economical and effective means of managing nematodes for resource-poor farmers. New and more productive varieties with resistance to nematodes are therefore, needed to increase and sustain productivity of yam cultivation.

Asiedu et al. (1998) showed that there is hope for the existence and management of genetic resistance in Dioscorea spp. According to Degras (1993) and Akoroda and Hahn (1995), substantial research investment has been made in the control of diseases and pests of yams and these efforts are continuing. However, the breeding for resistance against yam nematodes has been one of the most neglected research areas. This may be because of the genetically complex nature of the crop (Akoroda and Hahn, 1995) and few trained nematologists pursuing this goal. To breed such genotypes, sources of resistance in yams need to be identified. Also, reliable and reproducible screening methods are essential since escapes or misclassifications waste breeding effort and these have been developed and refined (Kwoseh et al. 2002). The objectives of this research were therefore to examine the variations in susceptibility of Dioscorea spp. to Scutellonema bradys, and identify sources of resistance for use in yam improvement programmes. The term 'resistance' in the context of this study refers to the degree of difficulty of multiplication of the nematode in either yam roots or tuber tissues (Cook and Evans, 1987).

\section{MATERIALS AND METHODS}

Juvenile and adult stages of Scutelonema bradys obtained from $S$. bradys-infected yam peelings was used for inoculation. The $S$. bradys populations were collected from various farmers' fields in the major yam growing zones in Ghana and the Kumasi Central market.

The yams used for the studies were obtained during a farmer-pest appraisal in the major yam agroecological zones in Ghana. Local and traditional yam varieties or landraces were collected from almost all the towns and villages visited in the districts. Selected yam varieties were screened for $S$. bradys resistance in pot and field experiments.

Yam plants were raised using the yam minisetts technique (Otoo et al., 1987). In this technique, the head region of the yam tuber was cut off and then the other portions sectioned horizontally into discs. Each disc was cut into parts with peel of the tuber. Setts weighing about $40 \mathrm{~g}$ were used for pot trials and $100 \mathrm{~g}$ for field trials. The cut surfaces of the setts were treated with Benlate-wood ash mix. The treated setts were then pre-sprouted in a quantity of sterilised moist coco-peat (shredded coconut husk) in plastic boxes in the screenhouse. The coco-peat was moistened with Benlate, a systemic fungicide $(25 \mathrm{~g} / 11$ litre water). The treated setts were spread on top of the coco-peat in a plastic box and then covered with another layer of moist coco-peat. This method was used to obtain more uniform plant establishment, tuber size and tuber maturity. Uniform plants of about 4 weeks old were used for the experiments.

\section{Assessment of yam varieties for nematode resistance}

Three sets of experiments were conducted to evaluate the reaction of test yam varieties of $D$. rotundata, D. alata, D. cayenesis, D. bulbifera, $D$. esculenta and D. dumetorum to $S$. bradys

\author{
Experiment 1: \\ Field evaluation of 40 Ghanaian yam varieties \\ for S. bradys resistance
}

34 Journal of Science and Technology, Vol. 27, No. 3, December 2007 
A total of 40 Ghanaian yam varieties $(26$ D. rotundata, two D. cayenensis, 11 D. alata and one $D$. dumetorum ) were screened for their reaction to $S$. bradys in a field experiment at the Crops Research Institute (CRI), Kumasi, Ghana (Table 1). Uniform plants from $100 \mathrm{~g}$ minisetts obtained as explained above were transplanted in mounds four weeks after sprouting at $1 \mathrm{~m}$ x $1 \mathrm{~m}$ planting spacing.

Two weeks after planting, each plant in the mound was infested with about 6,000 juvenile and adult stages of $S$. bradys (50 g $S$. bradysinfected yam peelings). A trench of about $5 \mathrm{~cm}$ from the stem of each plant was made around the plants in the mound and at a depth that exposed some of the roots. The chopped infected tuber peelings were then spread around the roots and covered again with the soil. A randomised complete block design (RCBD) with four replicates was used. The entries were harvested 36 weeks after transplanting and stored in baskets kept in an open-air yam barn. Visual nematode damage symptoms score (Kwoseh et al., 2002) and weight of tubers were recorded at harvest and at four and 11 weeks after harvest.

Each of the tubers in the screen was washed and peeled from the proximal to the distal end at two places and opposite to one another at four and 11 weeks after harvest for nematode extraction and counting. The yam tuber peelings were then chopped into 3 to $4 \mathrm{~mm}$ wide and about $1 \mathrm{~cm}$ long pieces for nematode extraction. Nematodes were extracted by the modified Baermann tray method (Whitehead and Hemming, 1965).

\section{Experiment 2:}

Confirmation test of 10 selected Ghanaian yam varieties of $D$. rotundata, $D$. cayenensis, $D$. alata and D. dumetorum for $S$. bradys resistance

Based on the results of Experiment 1 above, 10 different varieties and species of $D$. rotundata, $D$. cayenensis, D. alata and D. dumetorum namely Lili (D. rotundata), Chenchito (D. rotundata), Agyaasi (D. alata), Afun (D. cayenensis),
Yeremma (D. alata), Adi-amaaba (D. alata), Sante $(D$. rotundata), Matches (D. alata), Saabiri (D. alata) and Nkanfo (D. dumetorum) were used for a confirmation test in a field experiment. The study was done at the Crops Research Institute, Kumasi, Ghana. Plants from $100 \mathrm{~g}$ minisetts were pre-sprouted and planted in mounds. A randomised complete block design with five replicates was used.

The plants were infested with about 1,700 juvenile and adult stages of $S$. bradys $(50 \mathrm{~g} S$. bradysinfected yam peelings) two weeks after transplanting as in Experiment 1. The experiments were conducted at different seasons or times therefore peelings from the $S$. bradys-infested yam tubers used as sources of inoculum were different from Experiments 1 and 3. The entries were harvested 28 weeks after transplanting and then stored. Visual nematode injury score and tuber weight were recorded at harvest and eight weeks after storage. Each tuber was peeled and chopped eight weeks after storage and S. bradys was extracted and counted as described in Experiment 1.

\section{Experiment 3:}

Pot screening of seven selected Ghanaian yam varieties of $D$. rotundata, $D$. cayenensis, $D$. alata, D. dumetorum, D. bulbifera and D. esculenta for $S$. bradys resistance

Seven different yam varieties (D. rotundata var. Kyire-Kumasi, D. rotundata var. Chenchito $D$. rotundata var. Lili, D. cayenensis var. Afun, D. dumetorum var. Nkanfo and unknown variety of $D$. bulbifera plus an unknown variety of $D$. esculenta were evaluated in a pot experiment at the Department of Crop and Soil Sciences, Kwame Nkrumah University of Science and Technology, Kumasi, Ghana. Minisetts of $40 \mathrm{~g}$ of the yams were treated and pre-sprouted in sterilised cocopeat as described above. About four-week old plants of these yams were each potted into twolitre size pots containing about 1.5 litres of heat sterilised 2:1 soil-cocopeat mix. A simple line screening design with five replicates was used. 
The potted plants were allowed three weeks in the screenhouse to establish and then were each inoculated with about 800 active juvenile and adult stages of $S$. bradys (50 g chopped $S$. bra$d y s$-infected tuber peelings) in a similar way as described in Experiment 1. The inoculated plants were harvested nine weeks after inoculation. Roots and tubers of all test plants were washed and fresh weights taken separately and symptoms of nematode injury were scored (Kwoseh et al., 2002). Nematodes were extracted from washed roots or tuber peelings and the number of $S$. bradys counted. Each tuber was completely peeled. The roots or tuber peelings for each entry were chopped separately with a pair of scissors and then $5 \mathrm{~g}$ tissue of each was placed on to a two-ply facial tissue supported on a sieve placed in a plate. The set-up was left for $48 \mathrm{~h}$ under ambient conditions in the laboratory to collect the nematodes in a water suspension.

Data were transformed using square root for nematode counts and arcsin for percentages. Analyses of data were made using SAS Software Release 6.12 (1996).

\section{RESULTS AND DISCUSSION}

Experiment 1: Field evaluation of Ghanaian yam varieties for $\boldsymbol{S}$. bradys resistance

Analysis of variance revealed highly significant differences $(\mathrm{P}>0.001)$ between the yam varieties screened for $S$. bradys reaction. Mean $S$. bradys counts at four weeks ranged from 0 to $1073 / 5 \mathrm{~g}$ and from 0 to $1050 / 5 \mathrm{~g}$ at 11 weeks after storage (Table 1).

In general, the number of S. bradys and dry rot of tuber as well as tuber cracking increased during the storage period (Table 1). Dry rot and tuber cracking at harvest and after 11 weeks of tuber storage showed significant differences ( $P$ $>0.01)$ between varieties. The coefficients of variation $(\mathrm{CV})$ for the variables were high (Table 1). This may be because of the high variation in susceptibility between varieties.

It was observed that severely infected yam tu- bers with severe rot and cracking had large nematode populations. However, some infected tubers with symptoms recorded low nematodes counts (Table 1, e.g. TDr Labarko) probably because these tubers were either dried out or completely destroyed by dry rot disease with very little or no living tissue remaining.

Strong correlation $(r=0.9, r=0.5$ and $r=0.7)$ occurred between internal dry rot and tuber cracking at harvest and at four and 11 weeks after storage respectively. Dry rot of tubers also correlated positively $(\mathrm{r}=0.6)$ with $S$. bradys populations in the yam tubers. This relationship confirms that (Bridge et al., 2005) S. bradys causes internal dry rot of tubers resulting in external cracking of yam tubers. Following these results, dry rot symptoms could be effectively used to select for resistance to $S$. bradys in yam tubers either at harvest or after about four weeks of storage.

Based on $S$. bradys populations, all the Ghanaian yam varieties of $D$. rotundata and $D$. alata screened were susceptible. This agrees with Adesiyan (1977) and Bridge (1982) who examined yam cultivars from West Africa. D. dumetorum var. Nkanfo and D. cayenesis var. Afun were found to be resistant. D. dumetorum var. Nkanfo did not support reproduction and was not damaged by the nematode. According to Bridge et al. (2005), D. dumetorum is generally considered to be less susceptible to nematodes. In this study, these yams are considered resistant because they had zero or relatively low dry rot indices and supported very small nematode populations (Table 1).

\section{Experiment 2:}

Confirmation test of selected Ghanaian yam varieties of $D$. rotundata, $D$. cayenensis, $D$. alata and $D$. dumetorum for $S$. bradys resistance

The yam varieties generally produced large numbers of $S$. bradys in the tubers except on D. dumetorum var. Nkanfo and D. cayenensis var. Afun that recorded significantly smaller numbers

36 Journal of Science and Technology, Vol. 27, No. 3, December 2007 
Table 1: Reaction of Ghanaian yam varieties of D. rotundata (TDr), D. alata (TDa), D. cayenensis (TDc) and $D$. dumetorum (TDd) to $S$. bradys infection and populations in tubers after four and eleven weeks storage

\begin{tabular}{|c|c|c|c|c|c|c|c|c|c|c|}
\hline \multirow[b]{2}{*}{ Yam variety } & \multicolumn{3}{|c|}{${ }^{\mathrm{a}}$ Mean dry rot index } & \multicolumn{3}{|c|}{ Mean tuber cracking } & \multicolumn{4}{|c|}{$\begin{array}{l}\text { *Mean no. } S \text {. } \text { bradys } / 5 \text { g tuber peelings } \\
\text { Transformed }\end{array}$} \\
\hline & Harvest & $4 w k$ & $11 w k$ & Harvest & $4 \mathrm{wk}$ & $11 \mathrm{wk}$ & $4 \mathrm{wk}$ & $11 \mathrm{wk}$ & & ${ }^{b}$ Reaction \\
\hline TDa Yeremma & 1.5 & 1.5 & 2.3 & 1.5 & 1.3 & 2.0 & $31.9(8.8)$ & $29.5(15.4)$ & a & $\mathrm{S}$ \\
\hline TDa Saabiri & 0.5 & 1.3 & 1.8 & 1.0 & 1.3 & 1.8 & $18.5(9.3)$ & $28.1(16.4)$ & $a b$ & $\mathrm{~S}$ \\
\hline TDr Afi & 0.7 & 2.0 & 2.3 & 1.3 & 1.3 & 2.0 & $25.1(4.9)$ & $27.9(11.2)$ & $a b$ & $\mathrm{~S}$ \\
\hline TDr Sante & 0.5 & 1.3 & 2.0 & 1.3 & 1.0 & 1.5 & $27.2(13.3)$ & $27.8(11.5)$ & $\mathrm{abc}$ & $\mathrm{S}$ \\
\hline TDa Matches & 1.5 & 2.0 & 2.3 & 1.5 & 1.0 & 1.8 & $21.4(8.9)$ & $27.2(13.2)$ & $a-d$ & $\mathrm{~S}$ \\
\hline TDa Mmrefi & 0.5 & 0.8 & 1.3 & 1.0 & 1.0 & 1.0 & $15.1(16.4)$ & $25.8(14.3)$ & $a-d$ & $\mathrm{~S}$ \\
\hline TDr Nigeria & 1.0 & 1.5 & 2.0 & 1.0 & 1.3 & 1.8 & $29.9(12.2)$ & $25.7(14.0)$ & $a-d$ & $\mathrm{~S}$ \\
\hline TDa Afasie Kwandwo & 0.5 & 1.0 & 2.0 & 1.0 & 1.3 & 1.8 & $19.1(12.2)$ & $25.7(10.8)$ & a-d & $\mathrm{S}$ \\
\hline TDa Datordi & 1.8 & 2.0 & 2.5 & 1.8 & 2.0 & 1.8 & $29.5(9.3)$ & $24.9(11.1)$ & a-e & $\mathrm{S}$ \\
\hline TDr Accra & 2.0 & 2.0 & 2.3 & 2.0 & 1.5 & 2.0 & $29.0(5.7)$ & $21.5(7.8)$ & a-e & $\mathrm{S}$ \\
\hline TDr Tempe & 1.3 & 1.8 & 2.0 & 1.5 & 1.3 & 1.5 & $21.2(5.2)$ & $20.5(7.9)$ & a-e & $\mathrm{S}$ \\
\hline TDa Nsoadansi & 1.0 & 1.5 & 2.0 & 1.0 & 1.0 & 2.0 & $21.2(5.3)$ & $20.4(2.5)$ & a-e & $\mathrm{S}$ \\
\hline TDr Puna & 2.3 & 2.3 & 2.5 & 2.3 & 2.3 & 2.0 & $18.2(7.5)$ & $19.1(12.9)$ & $a-f$ & $\mathrm{~S}$ \\
\hline TDa Kyemogo & 0.8 & 1.0 & 1.3 & 1.3 & 1.3 & 1.3 & $16.8(7.9)$ & $18.8(6.0)$ & $a-f$ & $\mathrm{~S}$ \\
\hline TDc Abrewa nwo & 1.5 & 2.3 & 2.5 & 1.3 & 1.3 & 1.8 & $22.9(10.0)$ & $18.7(8.0)$ & $a-f$ & $\mathrm{~S}$ \\
\hline TDr Kpirindwo & 2.3 & 1.7 & 2.3 & 2.3 & 1.3 & 2.0 & $21.8(3.4)$ & $17.1(6.6)$ & $a-f$ & $\mathrm{~S}$ \\
\hline TDr Sanyata & 2.3 & 2.3 & 2.8 & 2.0 & 1.8 & 2.0 & $22.3(7.6)$ & $16.9(7.8)$ & $a-f$ & $\mathrm{~S}$ \\
\hline TDa Akaba & 1.8 & 2.5 & 2.5 & 1.5 & 1.5 & 1.8 & $27.7(4.9)$ & $16.8(7.1)$ & $a-f$ & $\mathrm{~S}$ \\
\hline TDr.Zong & 1.5 & 2.0 & 2.8 & 1.5 & 1.8 & 2.3 & $25.4(12.7)$ & $15.9(8.5)$ & $a-g$ & $\mathrm{~S}$ \\
\hline TDr Ziglanbgo & 0.8 & 1.8 & 1.5 & 1.3 & 1.5 & 1.5 & $21.5(10.8)$ & $15.2(7.6)$ & $\mathrm{a}-\mathrm{h}$ & $\mathrm{S}$ \\
\hline TDr Serwaah & 2.3 & 2.3 & 3.0 & 2.3 & 2.0 & 2.3 & $22.8(2.5)$ & $15.2(1.7)$ & $\mathrm{a}-\mathrm{h}$ & $\mathrm{S}$ \\
\hline TDa Kwaa-Asamoah & 1.3 & 2.0 & 2.0 & 1.3 & 1.3 & 1.5 & $35.0(11.4)$ & $14.6(4.6)$ & $\mathrm{b}-\mathrm{h}$ & $\mathrm{S}$ \\
\hline TDr Denteh & 1.3 & 1.5 & 2.0 & 1.5 & 1.3 & 1.5 & $15.3(3.5)$ & $13.7(3.7)$ & b-h & $\mathrm{S}$ \\
\hline TDr Dakpam & 1.3 & 1.0 & 1.5 & 1.5 & 1.3 & 1.5 & $11.6(8.9)$ & $13.1(8.8)$ & $\mathrm{c}-\mathrm{h}$ & $\mathrm{S}$ \\
\hline TDr Limor & 2.3 & 2.5 & 2.8 & 2.3 & 2.0 & 2.3 & $21.5(4.6)$ & $12.9(2.5)$ & $\mathrm{c}-\mathrm{h}$ & $\mathrm{S}$ \\
\hline TDr Sono bayere & 1.8 & 2.0 & 2.5 & 1.8 & 1.5 & 2.0 & $25.3(11.2)$ & $12.9(1.8)$ & $\mathrm{c}-\mathrm{h}$ & $\mathrm{S}$ \\
\hline TDr Moninyoli & 2.0 & 1.8 & 2.5 & 2.0 & 2.0 & 2.3 & $23.6(10.9)$ & $12.0(3.6)$ & $\mathrm{d}-\mathrm{h}$ & $\mathrm{S}$ \\
\hline TDr Muchumudu & 2.0 & 1.8 & 2.8 & 2.0 & 2.0 & 2.5 & $20.8(10.6)$ & $10.8(3.5)$ & $\mathrm{e}-\mathrm{h}$ & $\mathrm{S}$ \\
\hline TDr Dakorba & 2.0 & 2.0 & 2.5 & 2.0 & 1.8 & 2.5 & $17.7(2.2)$ & $10.0(7.0)$ & e-h & $\mathrm{S}$ \\
\hline TDr Kyire-Kumasi & 1.3 & 1.7 & 2.0 & 1.7 & 1.0 & 1.7 & $18.8(4.9)$ & $9.5(2.7)$ & e-h & $\mathrm{S}$ \\
\hline TDr Agyaasi & 1.3 & 1.5 & 2.3 & 1.0 & 1.3 & 1.8 & $15.4(4.1)$ & $9.2(1.0)$ & e-h & $\mathrm{S}$ \\
\hline TDr Kpiringa & 2.0 & 2.3 & 3.0 & 2.0 & 1.8 & 2.0 & $21.0(6.1)$ & $8.9(4.3)$ & $\mathrm{e}-\mathrm{h}$ & $\mathrm{S}$ \\
\hline TDr Chenchito & 2.5 & 2.5 & 3.0 & 2.0 & 2.0 & 2.5 & $27.7(4.9)$ & $8.9(4.0)$ & $\mathrm{e}-\mathrm{h}$ & $\mathrm{S}$ \\
\hline TDr Lili & 1.0 & 1.5 & 2.3 & 1.3 & 1.3 & 1.8 & $18.9(13.4)$ & $8.2(8.9)$ & e-h & $\mathrm{S}$ \\
\hline TDr Labarko & 2.0 & 2.0 & 2.7 & 2.3 & 2.7 & 2.7 & $7.7(4.3)$ & $7.2(4.9)$ & $e-h$ & $\mathrm{~S}$ \\
\hline TDr Fugla & 1.5 & 1.5 & 2.8 & 1.8 & 1.5 & 2.0 & $12.8(9.2)$ & $5.6(3.0)$ & fgh & $\mathrm{S}$ \\
\hline TDr Tela & 0.8 & 1.3 & 1.3 & 1.3 & 1.0 & 1.5 & $16.9(11.3)$ & $5.0(2.0)$ & fgh & $\mathrm{S}$ \\
\hline TDa Adi-amaaba & 0.5 & 1.0 & 0.8 & 0.8 & 1.0 & 1.0 & $8.3(4.6)$ & $4.7(5.7)$ & fgh & $\mathrm{S}$ \\
\hline TDc Afun & 0.3 & 0.3 & 0.3 & 0.8 & 1.0 & 1.0 & $1.6(1.2)$ & $1.8(1.5)$ & gh & $\mathrm{R}$ \\
\hline TDd Nkanfo & 00 & 00 & 00 & 0.5 & 0.5 & 1.0 & $0.7(0.0)$ & $0.7(0.0)$ & $\mathrm{h}$ & $\mathrm{R}$ \\
\hline $\mathrm{CV}(\%)$ & 58.4 & 35.9 & 31.3 & 39.1 & 34.9 & 25.3 & 42.9 & 50.3 & & \\
\hline
\end{tabular}

*Square root (Mean +0.5$)$ and SAS adjusted for missing data. ${ }^{a}$ Average of 4 replicates. Standard deviation in parentheses. Varieties followed by the same letter do not differ significantly according to Duncan's Multiple Range Test. ${ }^{b} S=$ susceptible, $R=$ resistant 
(Figure 1). D. alata var. Yeremma and D. rotundata var. Lili recorded the largest nematode counts (Figure 1). Dry rot and tuber cracking also differed significantly $(\mathrm{P}>0.01)$ between yam varieties in storage with $D$. rotundata var. Lili and D. alata var. Yeremma registering comparatively high dry rot disease scores (Table 2). This indicates that these visual disease symptoms are useful parameters for rating host resistance or susceptibility in yams.

In most cases, high dry rot symptoms were associated with high nematode numbers. There was strong correlation $(\mathrm{r}=0.7)$ between internal dry rot in tubers and $S$. bradys populations in tubers. Tuber cracking also strongly correlated $(\mathrm{r}=0.8)$ with internal dry rot symptoms.

Tuber weight loss of 16.0 to $74.5 \%$ was recorded over the eight-week storage period with $D$. rotundata var. Sante recording the largest weight loss while $D$. dumetorum var Nkanfo was the least affected (Table 2). Tuber weight reduction among the yam varieties was substantial and highly significant differences $(\mathrm{P}<0.01)$ were observed between them.

There was correlation $(\mathrm{r}=0.4)$ between tuber weight loss and dry rot disease. These results indicate that dry rot disease may have contributed to the tuber weight loss. According to Smit (1967), S. bradys caused a reduction of $20-30 \%$ in tuber weight. This study followed a similar trend as reported in the previous field trial (Experiment 1) and confirmed low multiplication of $S$. bradys in D. dumetorum var Nkanfo and D. cayenensis var. Afun (Figure 1).

S. bradys multiplied in the roots of all the yams in the screen with $D$. dumetorum recording the smallest numbers while, D. esculenta had the largest (Figure 2) although numbers in roots did not differ. It is interesting to have susceptible roots because this is likely to reduce pressure on the tuber.

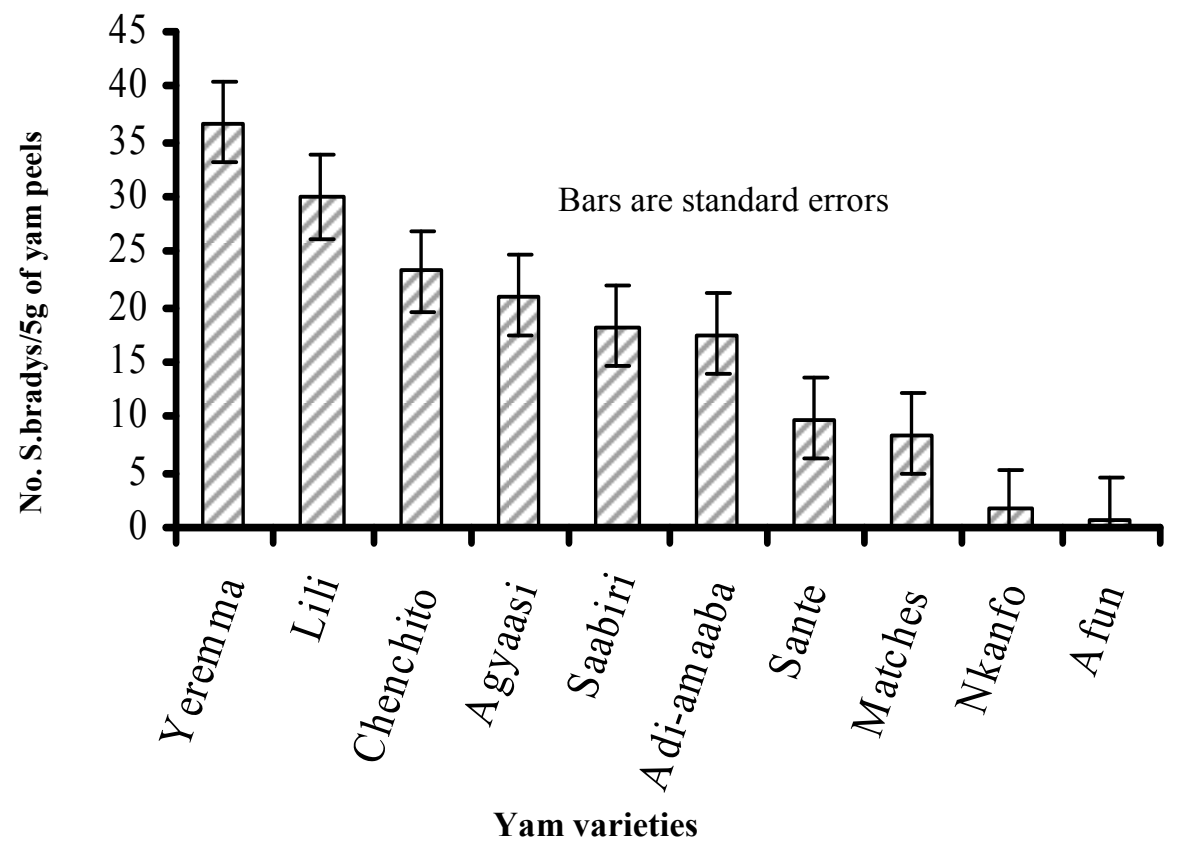

Fig. 1. Square root transformed populations of $S$. bradys in yams after eight weeks storage 
S. bradys numbers were generally larger in roots than in tubers with the resistors recording the smallest numbers (Figure 2). There were highly significant differences $(\mathrm{P}>0.01)$ between the yam varieties regarding $S$. bradys populations in the tubers.

Experiment 3: Pot screening of selected Ghanaian yam varieties for $\boldsymbol{S}$. bradys resistance

Dry rot symptoms and tuber cracking ranged between 0 and 2.4 and $D$. dumetorum var. Nkanfo was apparently symptomless (Table 3). Significant differences $(\mathrm{P}>0.05)$ were also observed between the yams for dry rot disease and tuber cracking.

There were strong correlations $(\mathrm{r}=0.7, \mathrm{r}=0.8)$ between dry rot disease and tuber cracking and number of nematodes in tubers respectively. The pot trial showed that visual damage caused by the yam nematode is useful for evaluation of resistance or susceptibility in Dioscorea.

Although roots supported $S$. bradys reproduction, there was no correlation between susceptibility in roots and tubers. This means that susceptibility in roots cannot be used to select for $S$. bradys resistance in yams. This is probably because the roots responded to stimulatory substances released by the nematode (Reddy, 1987) hence, created a favourable condition for their reproduction and multiplication. Also, it may be that there are nutrients or chemicals in the roots, which nematodes prefer. Developing roots are more tender than tubers so, this might have made it easier for $S$. bradys to penetrate and reproduce. The formation of roots and tubers and functions of these organs could also have played a role, and, probably there was a better $S$. bradys interaction in roots than in tubers.

Figure 2 illustrates the variation in resistance to $S$. bradys in Ghanaian yam varieties. This confirms the resistance of $D$. dumetorum var. Nkanfo and $D$. cayenensis var.Afun to $S$. bradys. The resistance exhibited by these varieties may be due to different physiological processes in them that make it impossible to meet the nutrient requirements of the nematode. This is not likely to be a species difference because $D$. cayenensis var. Abrewa-nwo is susceptible (Table 1). The resistance of $D$. cayenensis is very appreciable because it is easily compatible for hybridisation with D. rotundata (Kwoseh, 2000), the preferred

Table 2: Reaction of 10 selected Ghanaian yam varieties of $D$. rotundata (TDr), D. alata (TDa), D. $c$ ayenensis (TDc) and $D$. dumetorum (TDd) to $S$. bradys resistance at harvest and after eight weeks of storage

\begin{tabular}{|c|c|c|c|c|c|c|c|c|}
\hline \multirow[b]{2}{*}{ Yam variety } & \multicolumn{2}{|c|}{$\begin{array}{c}{ }^{\mathrm{a}} \text { Mean tuber } \\
\text { weight (g) }\end{array}$} & \multicolumn{2}{|c|}{ Tuber weight loss } & \multicolumn{2}{|c|}{$\begin{array}{l}\text { Mean dry } \\
\text { rot index }\end{array}$} & \multicolumn{2}{|c|}{$\begin{array}{c}\text { Mean tuber } \\
\text { Cracking }\end{array}$} \\
\hline & Harvest & 8 wk & \%Loss & ${ }^{*}$ Transformed & Harvest & 8 wk & Harvest & 8 wk \\
\hline TDr Lili & 265.1 & 212.3 & 22.1 & 27.9 & 1.3 & 3.0 & 1.0 & 2.3 \\
\hline TDa Adi-amaaba & 196.3 & 130.8 & 32.0 & 34.4 & 1.0 & 3.0 & 1.0 & 2.3 \\
\hline TDa Yeremma & 447.7 & 326.1 & 24.0 & 28.9 & 0.8 & 2.8 & 0.8 & 1.8 \\
\hline TDa Agyaasi & 97.2 & 54.7 & 49.6 & 44.7 & 0.6 & 2.6 & 0.8 & 1.8 \\
\hline TDr Chenchito & 55.3 & 35.5 & 36.6 & 36.9 & 0.8 & 2.4 & 0.8 & 2.0 \\
\hline TDa Sabiri & 162.1 & 134.6 & 31.0 & 33.2 & 1.0 & 2.2 & 1.0 & 1.6 \\
\hline TDa Matches & 55.6 & 28.3 & 42.8 & 40.5 & 0.7 & 1.3 & 0.7 & 1.3 \\
\hline TDr Sante & 64.9 & 12.1 & 74.5 & 60.1 & 1.0 & 1.0 & 1.0 & 1.0 \\
\hline TDc Afun & 194.4 & 151.0 & 23.1 & 28.6 & 0.2 & 0.2 & 0.2 & 1.0 \\
\hline TDd Nkanfo & 136.9 & 115.7 & 16.0 & 23.5 & 00 & 0.0 & 0.0 & 0.2 \\
\hline $\mathrm{CV}(\%)$ & 80.7 & 78.5 & 43.1 & 25.5 & 69.1 & 47.1 & 64.6 & 40.9 \\
\hline
\end{tabular}

* $\operatorname{Sin}^{-1}$ (\% weight tuber loss/100). ${ }^{a}$ Average of five replicates 


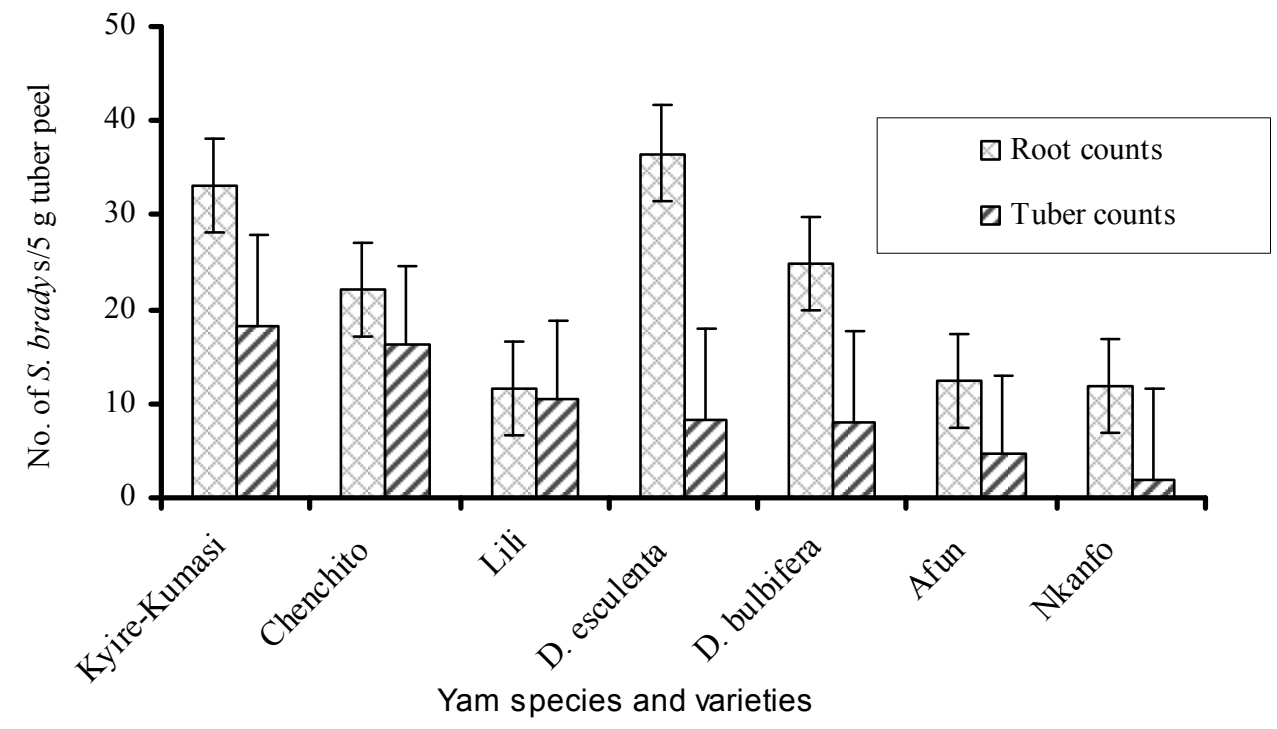

Fig. 2. Square root transformed populations of $S$. bradys in roots and tubers of yams

Table 3: Dry rot symptom scores in selected Ghanaian yam varieties of five Dioscorea species to $S$. bradys in pots nine weeks after inoculation

\begin{tabular}{lcc}
\hline \multicolumn{1}{c}{ Yam varieties \& species } & Mean* tuber cracking & Mean dry rot index \\
\hline TDr Chenchito & 2.4 & 2.4 \\
TDr Kyire-Kumasi & 2.0 & 2.0 \\
TDr Lili & 1.8 & 1.8 \\
TDc Afun & 0.8 & 1.0 \\
D. bulbifera & 0.5 & 0.7 \\
TDd Nkanfo & 0.5 & 0.0 \\
D. esculenta & 0.5 & 0.0 \\
CV $(\%)$ & 54.0 & 61.8 \\
\hline
\end{tabular}

*Average of five replicates. Yam species: TDr: D. rotundata, TDc: D. cayenensis, TDd: D. dumetorum

food or edible species. According to Asiedu et al. (1998), D. rotundata, D. praehensilis, D. cayenensis, D. dumentorum and D. burklilliana have been used in inter specific crosses and there are efforts in advanced laboratories aimed at somatic embryogenesis, somatic hybridisation and generic transformation.
In general, the benefit-to-cost ratio of breeding nematode resistant varieties is economically beneficial (Starr et al., 2002), particularly, to the resource-poor farmers. The identification of the resistant genotypes or sources of resistance would constitute the beginning of more focused effort in breeding for host plant resistance. Therefore, the 
information developed in this study should greatly help in yam breeding programmes for the continued search of nematode resistance in Dioscorea.

\section{CONCLUSIONS}

The conclusions derived from the study are as follows:

- In general, S. bradys population density and dry rot disease of yam tuber as well as tuber cracking increased with storage. This shows that the yam nematode is a serious storage pest.

- $\quad$ An efficient, positive pot and field screening methodologies with improved precision have been developed to make meaningful selections from yam germplasm.

- Results demonstrated a linear relationship between nematode damage and population densities in yam tubers, implying visual disease symptoms are useful parameters for rating host resistance in yams. Dry rot symptoms of yams could therefore be used to discard susceptible yam varieties at harvest and after a period of storage.

- $\quad$ There was no correlation between $S$. bradys susceptibility in roots and tubers, therefore, within the limits of this study a root protocol cannot be used for assessing resistance in yams as it could give misleading classification.

- $\quad$ Based on S. bradys populations, all the yam varieties of $D$. rotundata and $D$. alata in the screen were susceptible however, there was a high variation in susceptibility between the yam varieties.

- Tuber weight reduction among the yams was substantial after a period of storage. There was also a positive correlation between tuber weight loss and dry rot disease indicating that dry rot disease may have contributed to the tuber weight loss.

- D. dumetorum var. Nkanfo and $D$. cayenensis var. Afun were resistant to $S$. bradys. These yams are considered resistant because they did not support multiplication of $S$. bradys or had relatively smaller dry rot damage and supported very small nematode populations.

- Mass screening of yam germplasm using the yam minisett both in field and pot trials is practical and convenient considering the cost of tissue culture material. Mounds and ridges should be infested with infected yam peelings to avoid escapes.

\section{REFERENCES}

Adesiyan, S. O. (1977). Penetration and multiplication of Scutellonema bradys in yams (Dioscorea spp.). Nematologia mediterranea 5: $313-317$.

Adesiyan, S. O., Caveness, F. E., Adeniji, M. O. and Fawole, B. (1990). Nematode pests of tropical crops. Heinemann Educational Books (Nigeria) Limited.114 pp.

Akoroda, M. O. and Hahn, S. K. (1995). Yams in Nigeria: status and trends. African Journal of Root and Tuber Crops 1: 37-41.

Asiedu, R., Ng, N. Y. C., Bai, K. V., Ekanayake, I. J. and Wanyera, N. M. W. (1998). Genetic improvement. In: Food yams: Advances in research, (eds.) G. C. Orkwor, R. Asiedu and I. J. Ekanayake. pp. 63-104.

Bridge, J. (1982). Nematodes of yams. In: Yams. Igname, (eds.) J. Miege and S. N. Lyonga, Clarendon Press, Oxford. pp. 253-264.

Bridge, J., Coyne, D. L. and Kwoseh, C. K. (2005). Nematode parasites of tropical root and tuber crops. $2^{\text {nd }}$ Edition. In: Plant Parasitic nematodes in subtropical and tropical agriculture, (eds.) M. Luc, R. A. Sikora and J. Bridge, CAB International, UK. pp. 221258.

Cook R. and Evans, K. (1987). Resistance and tolerance. In: Principles and practice of nematode control in crops, (eds.) R. H. 
Brown and B. R. Kerry. Academic Press. pp.179-231.

Coursey, D. G. (1967). Yams. Longmans, Green and Co. Ltd., London.. 230 pp.

Degras, L. M. (1993). The Yam: A tropical Root Crop. The Technical Centre for Agricultural and Rural Cooperation (CTA). The MacMillan Press, London. 408 pp.

Emehute, J. K. U., Ikotun, T., Nwauzor, E. C. and Nwokocha, H. N. (1998). Crop p r o tection. In: Food yams: Advances in Research, (eds.) G. C. Orkwor, R. Asiedu and I. J. Ekanayake. pp. 141-186.

Jatala, P. and Bridge, J., (1990). Nematode parasites of root and tuber crops. In: Plant Parasitic nematodes in subtropical and tropical agriculture, (eds.) M. Luc, R. A. Sikora and J. Bridge, CAB International, UK. pp.137 - 180.

Kwoseh, C. K. (2000). Identification of resistance to major nematode pest of yams (Dioscorea spp.) in West Africa. PhD thesis. Dept of Agriculture, University of Reading, UK.196 pp.
Kwoseh, C., Plowright, R. A. and Bridge, J. (2002). The yam nematode: Scutellonema bradys. In: Plant resistance to parasitic nematodes, (eds.) J. L. Starr, R. Cook and J. Bridge, CAB International, UK. pp.258.

Otoo, J. A., Osiru, D. S. O, Ng, S. Y. C and Hahn, S. K. (1987). Improved technology for seed yam production. IITA, Ibadan, Nigeria. $56 \mathrm{pp}$.

Plowright, R. A and Kwoseh, C. K. (1998). Farmers perceptions of nematode disease in yams in Ghana and the prevalence of endoparasitic nematodes in stored tubers. Nematologica 44: 558-559 (Abstract).

Reddy, P. P. (1987). A treatise on phytonematology. Agricole Pub. Academy, India.381 pp

SAS (1996). SAS Institute Incorporated, Cary, NC, USA.

Starr, J. L., Bridge, J. and Cook, R. (2002). Resistance to plant-parasitic nematodes: History, current use and future potential In: Plant resistance to parasitic nematodes, (eds.) J. L. Starr, R. Cook and J. Bridge, CAB Interna-

42 Journal of Science and Technology, Vol. 27, No. 3, December 2007 